\title{
Biochemical Characterization of Nucleotidase in some Parasites
}

\author{
${ }^{1}$ Ilham A. A. AL-Tikrity, ${ }^{2}$ Abeer A.A. Alattar, ${ }^{3}$ Harith Ahmed Mustafa \\ ${ }^{4}$ Safaa.M.Sultan, ${ }^{5}$ Wasan Talib Abed \\ rahmasw90@gmail.com ${ }^{1}$,abeeralatar@ntu.edu.iq ${ }^{2}$, harithahmed684@gmail.com ${ }^{3}$ \\ safaahawija@gmail.com ${ }^{4}$, abeeralatar@ntu.edu.iq ${ }^{5}$ \\ Tikrit University ${ }^{1}$, Northern Technical University ${ }^{2}$, Samarra University ${ }^{3}$ \\ Northern Technical University ${ }^{4}$, Northern Technical University ${ }^{5}$, Iraq
}

\begin{abstract}
The activity and properties of Nucleotidase in the extract of Leishmania Tropica, Fasciola hepatica, and Moneizia expensa were studied by using Fisk \& subbarow agent method. the optimum conditions were determined to measure the enzyme activity from the $\mathrm{pH}$, the temperature and the time required for incubation where the specific efficacy was $28.8,52.3,28.6$, micromol phosphate / $\mathrm{min} / \mathrm{mg}$ protein.
\end{abstract}

Keyword: Nucleotidase, Fasciola hepatica, Leishmania tropica, Moneizia expensa, temperature, $\mathrm{pH}$

\section{Introduction}

The Nucleotidaes from phosphor-enzyme mono-esterase which works into Nucleosides Monophosphate Which removes inorganic phosphate group esterifies with a carbon atom in phosphorylated sugars of nucleotide molecules (De-oxey Ribose) [1]. It has a major role in the transmission of nerve signals and regulates the production of Adenylate cyclase and conversion of adenosine triphosphate ATP to the nucleoside used in the recovery of nucleotidaes [2]. His role is limited to regulate the level of these nucleotidaes either by putting them out of cells [3] or in the process of building or undermining these compounds [4]. Nucleotide enzyme is widespread in various organisms, including parasitic worms such as Monizia Expansa, Monizia benedeni, Fasciola hepatica, and Dirofilaria immitis [5,6]. Given the importance of this enzyme and its metabolic role within cells, this study includes a comparison of some nucleotidase properties of three parasites of different taxonomic groups related to animal health.

\section{Material \& Methods}




\subsection{Source of parasites}

Leishmania tropica (MHOM / SU/ 74 / K27) promasigotes were grown at $26{ }^{\circ} \mathrm{C}$ and harvested as described previously [7]. Washed parasites were stored as pellets at $-70{ }^{\circ} \mathrm{C}$ until use.

Adult Fasciola hepatica was collected from the bile duct of cattle and Monizia expansa from intestine of sheep freshly slaughtered at the local abattoir in Kirkuk and washed clean of host's tissue in normal saline.

\subsection{Preparation of crude homogenate and cellular fractionation}

All procedures were performed at $4{ }^{\circ} \mathrm{C}$. Promastigotes of Leishmania tropica, Fasciola hepatica and Moneizia expansa were lysed in TSD buffer containing $50 \mathrm{mM}$ Tris- Hcl (pH 7.6) containing $0.25 \mathrm{M}$ sucrose and $0.1 \mathrm{~m} \mathrm{M}$ dithiothritol by three cycles of $10 \mathrm{~min}$. freezing in liquid nitrogen and thawing at $25{ }^{\circ} \mathrm{C}$. The resulting homogenate was centrifuged for $1 \mathrm{hr}$. at $105000 \mathrm{x}$ $\mathrm{g}$ at $4{ }^{\circ} \mathrm{C}$. The material sediment (pellet) was removed, resuspended in TSD buffer in the same volume as supernatant recovered. To investigate the subcellular localization of the enzyme, the promasigote Leishmania tropica, Fasciola hepatica and Moneizia expansa were lysed as described above in TSD buffer containing 0.2\% Triton x-100 and subjected to differential centrifugation as previously described [8], yielding partial fraction P1 (2100 xg for $10 \mathrm{~min}$.), P2 (15800xg for $10 \mathrm{~min}$.) and P3(24000xg for $1 \mathrm{hr}$.).The four fractions produced were frozen and thawed thrice to disrupt organelles and were assayed for enzyme activity.

\subsection{Enzymatic Assay}

In all experiments designed to the detection of nucleotidase activity was conducted at $37^{\circ} \mathrm{C}$ for 3 minutes in a $1 \mathrm{~mL}$ reaction volume of $50 \mathrm{mM}$ Tris- $\mathrm{HCl}$ buffer $(\mathrm{pH} 7.2), 1.0 \mathrm{mM} \mathrm{MgCl} 2$. The reaction was initiated by the addition substrate (adenosine mono-phosphate AMP-5). After 30 min, the reaction has stopped the reaction by adding $1 \mathrm{ml}$ of TCA $8 \%(\mathrm{w} / \mathrm{v})$ and the resulting mixture was centrifuged at $2000 \mathrm{~g}$ for $10 \mathrm{~min}$. at $4{ }^{\circ} \mathrm{C}$. Liberated inorganic phosphate (Pi) was determined by the method of Fisk and Subbarow [9]. One unit of nucleotidase activity is defined as the amount of enzyme which hydrolyses $1.0 \mu \mathrm{mol}$ of nucleotides per min. per mg protein.

Protein determination: Protein concentration was estimated by the method of Lowery et al. with bovine serum albumin as standard.

Statistical Analysis: All data expressed as mean from triplicate experiments.

\section{Results and discussion}


The activity of the nucleotidase was determined in the extracts of Leishmania, Fasciola, Moniazia and prepared parasite cells as in the previous paragraph of the materials and methods of work. Table (1) shows that the highest activity was observed in the pellet are 1.32, 2.27 and $3.29 \mu \mathrm{mol} / \mathrm{min} / \mathrm{mg}$ protein in Leishmania, Fasciola and Moniazia, respectively. This indicates the presence of the nucleotide enzyme in the cytoplasmic membranes of different cells and organelles. These results are similar to the results of other studies, as this enzyme was studied in the Fasciola parasites, Dirofilaria immitis and Moniazia bendini [6], as well as in some protozoan [10] and helminths [11] parasites.

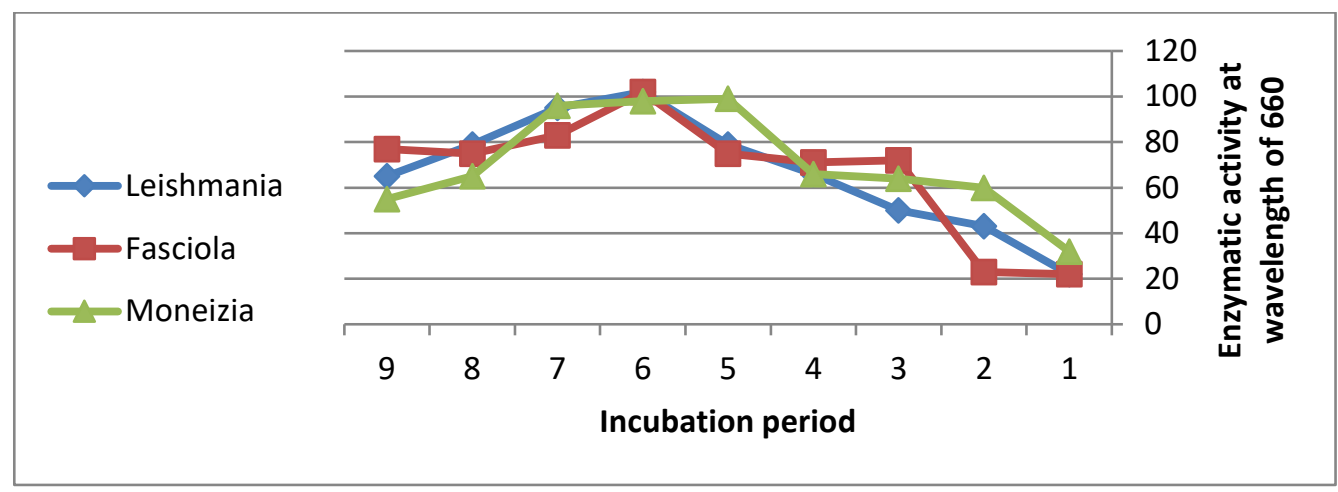

Figure (1) The effect of the incubation period of the reaction on the activity of the nucleotide enzyme in the extract of Leishmania, fasciola and Monizia

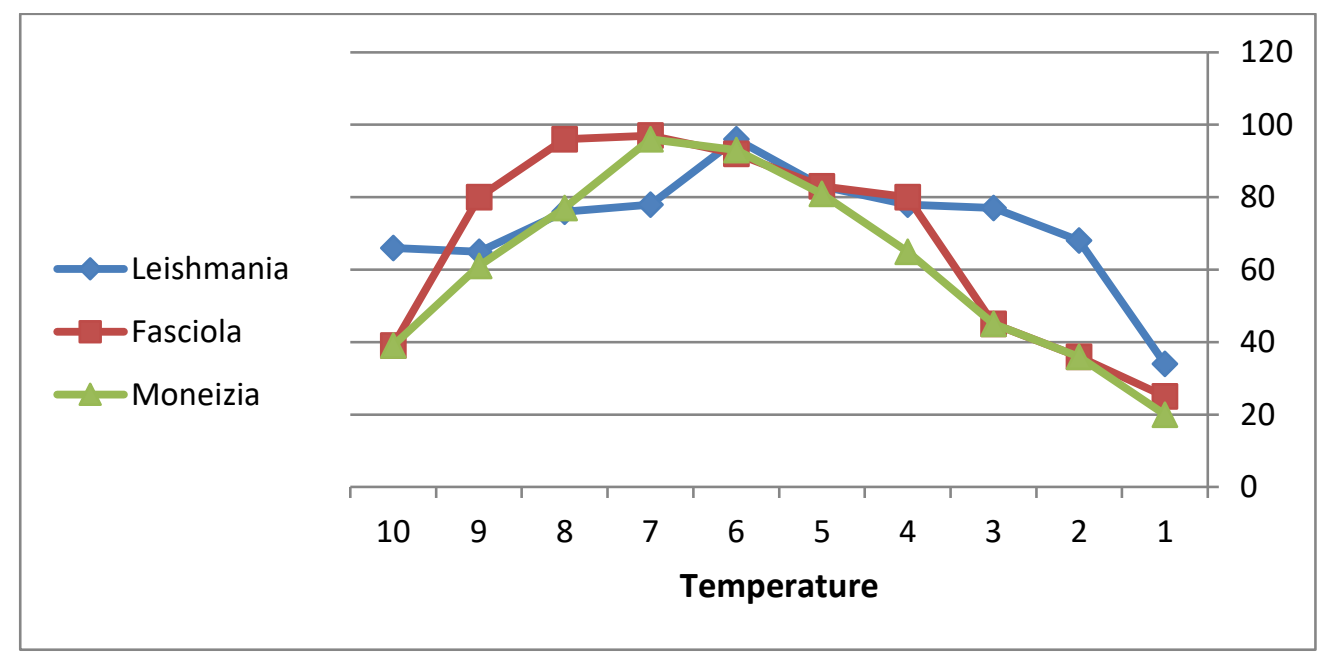

Figure (2) The effect of the reaction temperature on the efficacy of the nucleo-tidase enzyme in the extract of Leishmania, fasciola and Monizia.

The enzyme activity was measured in regular and successive incubation periods for a period of 50 minutes, as shown in Figure (1). It was observed that the total activity increases linearly, with 
an increase in the incubation period and then begins to decrease after a period and reached maximum effectiveness of $100 \%$ after 30 minutes for both Leishmania and Fasciola. While it was after 35 minutes in Monizia then continued incubation for 50 minutes. This may be due to the used up of the enzyme or the substrate from the reaction solution. This is similar to results that confirmed 30 minutes as the optimal period to obtain the highest efficacy of this enzyme [10].

The effect of different temperatures on the enzyme activity. It was found that the optimum temperature, as shown in Figure 2, was $37^{\circ} \mathrm{C}$ with respect to the enzyme isolated from Leishmania. And $30^{\circ} \mathrm{C}$ for the enzyme in both Fasciola and Moniazia, and this corresponds to the results that concluded that the optimum temperature for the effectiveness of this enzyme in humans and sheep was $37^{\circ} \mathrm{C}[12,13]$. As well as the results examined this enzyme in different parasites [10]. This may indicate that the parasites adapted themselves to the host body temperature, and the increase in temperature leads to the inability of the enzyme to play its catalytic role due to the change in the natural form of the enzyme with a rise in temperature confirming this decrease in the effects observed in its results.

Table (1): Cellular fractionation of the Nucleotides in different parasite extract

Leishmania (L), Fasciola (F) and Moniazia (M)

\begin{tabular}{|r|c|c|c|c|c|c|}
\hline Fractions & \multicolumn{7}{|c|}{ Total activity } & \multicolumn{3}{r|}{ Specific activity $\boldsymbol{\mu m o l} / \mathbf{m i n} / \mathbf{m g}$ protein $\pm \mathbf{S E}^{*}$} \\
\hline & $\mathrm{M}$ & $\mathrm{P}$ & $\mathrm{L}$ & $\mathrm{M}$ & $\mathrm{F}$ & $\mathrm{L}$ \\
\hline $\begin{array}{l}\text { Crud } \\
\text { homogenate }\end{array}$ & 100 & 100 & 100 & $0.4 \pm 7.82$ & $0.3 \pm 7.24$ & $0.14 \pm 8.17$ \\
\hline Pellet (p) & 375 & 376 & 393 & $0.32 \pm 29.3$ & $0.23 \pm 27.2$ & $0.4 \pm 32.1$ \\
\hline Supernatant & 55 & 40 & 75 & $0.05 \pm 4.3$ & $0.16 \pm 2.9$ & $0.06 \pm 6.1$ \\
\hline
\end{tabular}

* The standard rate and error is for three replicates

Figure (3) showed the effect of the $\mathrm{pH}$ on the activity of the nucleotidase. It was found that the best activity was at pH 8.0 in Leishmania, 7.4 in Fasciola and 7.8 in Moniazia. This contradicts the results of [14] and found that the optimum $\mathrm{pH}$ for the effectiveness of this enzyme in Fasciola was 8.5 and in Moniazia bendni was 8.0. But its similar to the value of this enzyme in Leishmania [15], and this confirms the differential effect of the $\mathrm{pH}$ on the nature of the enzyme, its chemical composition, and the various ionic groups it carries. Various binary ions were used in similar concentrations to determine their effect on the activity of the nucleotides. They were incubated with the reaction mixture in optimal conditions of temperature, $\mathrm{pH}$ and incubation period as in Table (2). 


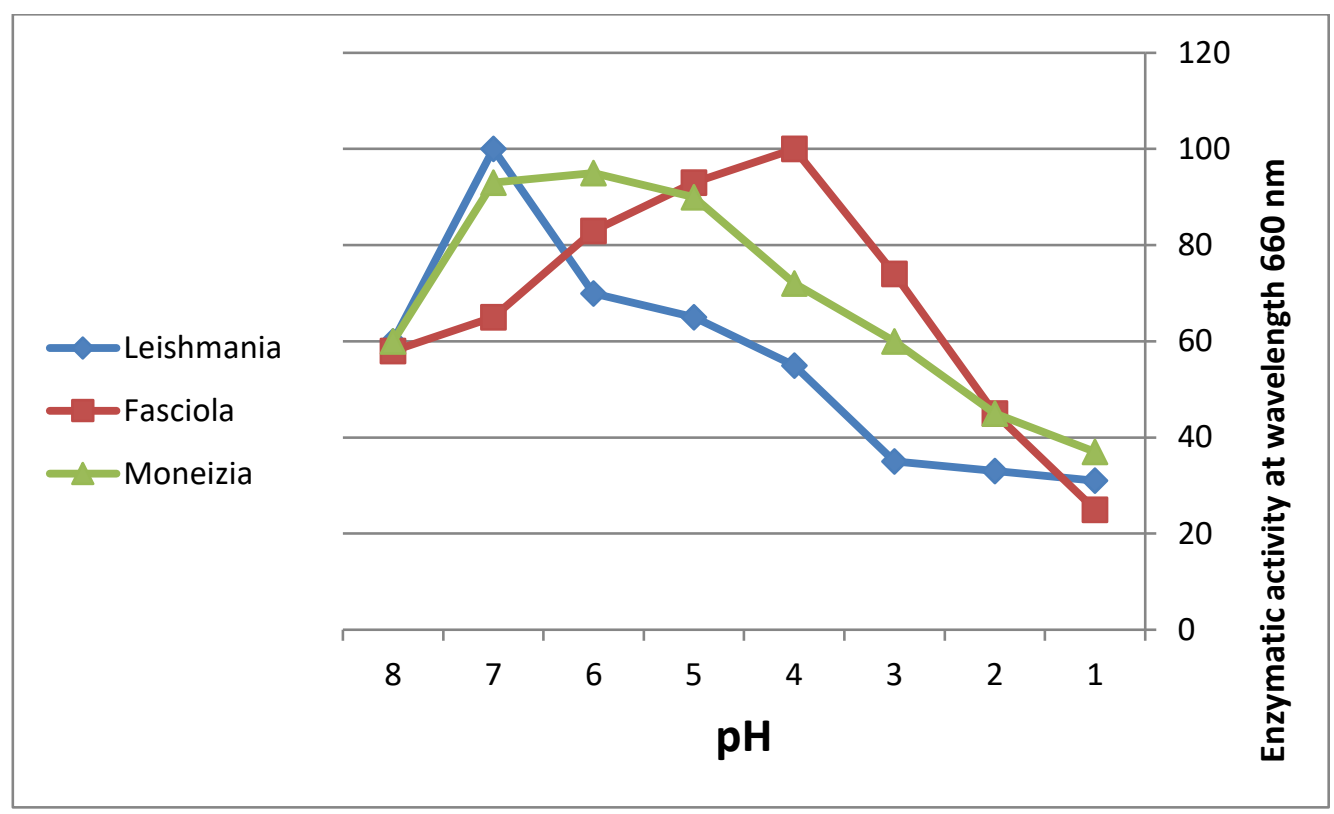

Figure (3) Effect of the acidic function on the activity of the nucleotidase enzyme in the extract of parasitoid Leishmania, fasciola and Monizia (the solutions used are $50 \mathrm{mM}$, sodium acetate is $\mathrm{PH}=5-6.5 \mathrm{mM}$ molar, $\mathrm{Hcl}=7-8.5$.

Table (2): Effect of divalent cations on the activity of the nucleotides in Leishmania (L), Fasciola (F), and Moniazia (M)

\begin{tabular}{|c|c|c|c|c|}
\hline Ions & Concentration (mM) & \multicolumn{3}{|c|}{ Activity\% } \\
\hline & & $\mathrm{M}$ & $\mathrm{F}$ & $\mathrm{L}$ \\
\hline $\mathrm{Mg}^{++}$ & 5 & 110.1 & 180 & 191.3 \\
\hline $\mathrm{Zn}^{++}$ & 5 & 68.4 & 79.8 & 84.8 \\
\hline $\mathrm{Ca}^{++}$ & 5 & 101.5 & 152.7 & 187.4 \\
\hline Control & 0 & 100 & 100 & 100 \\
\hline
\end{tabular}


Table (3): Nucleotidase activity by using alternative substrate in the reaction mixture of Leishmania (L), Fasciola (F), and Moniazia (M)

\begin{tabular}{|c|c|c|c|c|c|c|}
\hline \multirow[t]{2}{*}{ Sub striate } & \multicolumn{3}{|c|}{$\begin{array}{r}\text { The specific activity } \\
\text { SE }^{* *} \pm\end{array}$} & \multicolumn{3}{|c|}{ Activity\%*** } \\
\hline & $\mathrm{L}$ & $\mathrm{F}$ & $\bar{M}$ & $\mathrm{~L}$ & $\mathrm{~F}$ & $\bar{M}$ \\
\hline 5-AMP & $0.09 \pm 30.8$ & $0.07 \pm 25.2$ & $0.09 \pm 28.7$ & 100 & 100 & 100 \\
\hline Cyclic-AMP & $0.24 \pm 14.4$ & $0.16 \pm 10.3$ & $0.07 \pm 11.2$ & 47 & 41 & 39 \\
\hline$\overline{\mathrm{ATP}}$ & 0.0 & 0.0 & 0.0 & 0.0 & 0.0 & 0.0 \\
\hline
\end{tabular}

*The specific activity represents the number of nanomoles of organic phosphate / nanomolar base material/minute/mg protein.

**Three-repeat standard rate and error

****The percentage calculated according to the highest efficacy is $100 \%$.

It was found that the addition of calcium and magnesium ions led to increasing the enzymatic activity, while the zinc ions act as the inhibitory effect of enzymatic activity compared to with the control group of the three parasites. This contrasted with results that demonstrated that the magnesium and Calcium ion had a "catalytic" effect of the enzyme and that Zinc ion has an "inhibitory" effect, or it does not show any effect on the enzymatic activity [10,12]. This indicates that the enzyme activity depends on divalent cations, and this is similar to what is found in other biological systems $[15,16,17,18]$. However, when trying to use cyclic AMP and ATP substrate as a substitute for the usual 5-AMP substrate, it was found as shown in Table (3), the specific activity decreased when using cyclic AMP and was absent when using ADP. This indicates the difference in the specificity of this enzyme, the main substance according to its different source, but it is most likely considered a specialized gene working on the nucleus 5 purine and pyrimidine monophosphate.

\section{Reference}

1- Lee, S. Y., Fiene, A., Li, W., Hanck, T., Brylev, K. A., Fedorov, V. E, \& Sévigny, J. (2015). Polyoxometalates-potent and selective ecto-nucleotidase inhibitors. Biochemical pharmacology, 93(2), 171-181.

2- Kavatchu, M. and Melzig, F.(1999). in vetro effect of selected flavonoids on the 5nucleotidase activity. Phormaze ,54(6) : 457-459.

3- Holmes, A. P., Nunes, A. R., Cann, M. J., \& Kumar, P. (2015). Ecto-5'-nucleotidase, adenosine and transmembrane adenylyl cyclase signalling regulate basal carotid body 
chemoafferent outflow and establish the sensitivity to hypercapnia. In Arterial Chemoreceptors in Physiology and Pathophysiology (pp. 279-289). Springer, Cham.

4- Gohara, D. W., \& Yap, M. N. F. (2018). Survival of the drowsiest: the hibernating $100 \mathrm{~S}$ ribosome in bacterial stress management. Current genetics, 64(4), 753-760.

5- Hassan, H. F: Khoresheed, S. H .and Majeed, N. F. (1998). Partial purification of 5 Nucleotidase from Parasitic cestods Monizia expansa, Tikreet University. J.Sci.4(2) :13-25.

6- AL-Aubaidy, S.Sh (2007) . Study activity of some phosphomonoesterase enzyme in some parasitic helminthes. $\mathrm{Ph}$.D thesis, College of Education. Tikreet University.

7- Husain F.Hassan and Abeer A.Ali.(2016), Partial Purification and Properties of Adenosine Triphosphatase (ATPase) From Leishmania tropica., Int. J. Curr. Res. Aca. Rev.; 4(12): 54-63.

8- Husain F.Hassan and Abeer A.Ali.(2014), Partial purification and properties of adenosine triphosphatase (ATPase) from liver fluke Fasciola hepatica. Turkiye Parazitol Derg. ;38(1):26-31.

9- Fisk, C. and Subbarow, Y. (1925), The Colorimetric method of estimation of inorganic phosphate, J. Biol. Chem., 66:375-400.

10- Hassan, H.: Phillips,R. and Coombs,G., (1987), Purine metabolizing enzyme in Babesia divergens, J.Parasitole.Res.73:121-125.

11- Zangana, Soma Adnan Mardan, (2005), Purine metabolism in a number of helminths of different taxonomic groups. Master Thesis, College of Education, Tikrit University.

12- Al-Ta'i, Asraa Ismail Yassin, (2006), A biochemical study of 5-nucleotide enzyme symmetries partially purified from the blood serum of anemic patients. Master Thesis, College of Education for Girls, Tikrit University.

13- Khorshid, Sabah Hussain (1995). Purification of the nucleotide enzyme and cyclic nucleotide phosphodiesterase from sheep liver. Master Thesis. College of Education for Girls, Tikrit University.

14- Mateus Fracasso Aleksandro S. Da Silva Matheus D. Baldissera Nathieli B. Bottar (2017) Activities of ectonucleotidases and adenosine deaminase in platelets of cattle experimentally infected by Fasciola hepatica. Experimental Parasitology, 176: 16-20.

15- Pereira NM, (1981). A nucleotidase from Leishmania tropica Promastigotes: partial purification and properties, Tropenmedizin und Parasitologie, 32(4):209-214. 
16- Prasad, A. S. (2017). Discovery of Zinc for Human Health and Biomarkers of Zinc Deficiency. In Molecular, Genetic, and Nutritional Aspects of Major and Trace Minerals (pp. 241-260). Academic Press.

17- Nalini, P., Ellaiah, P., Prabhakar, T., \& Girijasankar, G. (2015). Microbial alkaline phosphatases in bioprocessing. Int. J. Curr. Microbiol. App. Sci, 4(3), 384-396.

18- Sinha, P., Paswan, R. K., Kumari, A., Kumar, S., Bimal, S., Das, P., \& Lal, C. S. (2016). Magnesium-Dependent Ecto-ATP Diphosphohydrolase Activity in Leishmania donovani, Current microbiology, 73(6), 811-819. 